\title{
Simulated Cattle Injury to Planted Slash Pine: Combinations of Defoliation, Brows- ing, and Trampling
}

\author{
CLIFFORD E. LEWIS
}

\begin{abstract}
Cattle injure young pines by defoliating, browsing, and trampling them. Little is known about how these injuries at various levels and in various combinations will affect survival and growth of planted pines. Therefore, such injuries were simulated once on slash pine at 6,18 , and 30 months after planting by (1) hand clipping to remove needles, (2) clipping off the shoots, and (3) bending the stem at a right angle to the vertical. Survival was poorest when treatments were applied to seedlings within 6 months after planting, whereas mortality was low when older seedlings were treated. Only the severest treatments, especially combinations of injury, caused extreme mortality. Seedlings treated at 6 months after planting suffered greater reductions in height growth than did the older seedlings. Only the severest combinations of injury permanently reduced height growth.
\end{abstract}

Although cattle have been known to destroy young pine plantations, such stands suffer little damage if cattle numbers are balanced with the forage supply (Wahlenberg et al. 1939; Wakeley 1954; Smith et al. 1958; Hilmon et al. 1963; Pearson et al. 1971; Adams 1975). However, cattle sometimes graze pine foliage (Pearson 1976; Williston 1974; Cassady et al. 1955) and some injury can be expected from trampling and browsing of twigs.

Rating the types of livestock damage that prevent young pines from achieving normal growth and form has proved difficult. Thus, no quantitative data are available on the relationship of mortality, slow growth, or poor form to the kinds of injury sustained by seedlings and saplings. Moreover, researchers generally have failed to distinguish between injury and damage (that is, the loss of growth resulting from injury).

This study represents an attempt to solve these problems by simulating injury by cattle to seedlings of slash pine (Pinus elliottii Engelm.). Grazing, browsing, and trampling were simulated by clipping needles, removing new shoot growth on stems and branches, and bending stems. The treatments were applied systematically in combinations encompassing the range of each type of injury. Survival and

\footnotetext{
The author is principal range scientist, Southeastern Forest Experiment Station, Forest Service, U.S. Department of Agriculture, Marianna, Florida 32446.

This was a cooperative study by the Georgia Coastal Plain Experiment Station, University of Georgia, College of Agriculture, Tifton, Ga., and the Forest Service, USDA. Acknowledgment is given to Dr. Karl F. Wenger, whose idea prompted the study, and Ralph $\mathbf{H}$. Hughes, who initiated it.

Manuscript recevied March, 12, 1979.
}

height growth for six growing seasons after treatment are reported.

\section{Methods}

\section{Study Location}

A 1.2-ha typical flatwoods site in the Lower Coastal Plain was selected on the Alapaha Experimental Range in Berrien County, Georgia. This site was an old field that had not been cultivated or fertilized since about 1920. Frequent burning and almost continuous grazing had produced a uniform cover of carpet grass (Axonopus affinis Chase) with a few scattered pines.

Soil at the study site is classified as Plummer fine sand, which is very wet, acid, and light-textured. Water movement through its surface horizons is moderately free; natural fertility is low. The Plummer series is a member of the loamy, siliceous, thermic family of Grossarenic Paleaquults (formerly classified as Low-Humic Gleys).

In 1958, all large pines were removed from the site and burning was curtailed. The area was prepared in January 1960 for installation of the study by removing all stumps; cutting all weeds, grass, and small trees with a rotary mower; and installing a fence to prevent grazing. Thereafter, unplanted areas were mowed before each new planting.

\section{Experimental Design}

The design was a split-plot, randomized block. Each treatment was applied to seedlings of three ages and was replicated in three blocks and in three separate years. Year of planting was the main plot effect. The three ages at time of treatment were handled as separate tests. Treatments were assigned at random to transects of five trees that were separated by two or more trees. Each transect was permanently identified.

\section{Treatments}

Healthy, 1-year-old slash pine seedlings were machine planted at a spacing of 1.2 by $2.4 \mathrm{~m}$ in January of 1960, 1961, and 1962 . Treatments were applied from late April to early June during 1960 through 1964 at 6,18 , and 30 months after planting as soon as new needles were fully developed.

Needle removal consisted of hand clipping 0,50 , and $100 \%$ of the length of all needles on a seedling (Fig. 1).

Shoot removal involved clipping the current year's growth from 0,50 , and $100 \%$ of the shoots on the main stem and branches. For the $50 \%$ treatment, removal began with the terminal leader and then proceeded on each even-numbered branch, moving clockwise from the topmost branch on the north side of the tree. When young seedlings lacked lateral branches, the 50 and $100 \%$ treatments were 


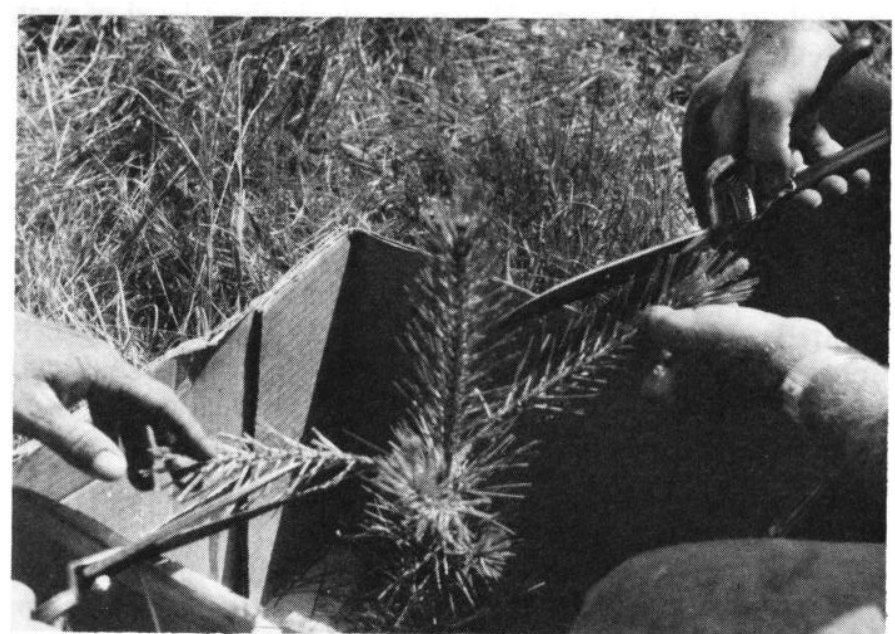

Fig. 1. Injury by cattle was simulated by clipping a portion of the needles from slash pine seedlings.

identical.

Stem bending or breakage, such as may occur from trampling, was accomplished by stepping on a seedling and bending it at a right angle to the vertical. A heavy wire hook placed behind each seedling facilitated a $90^{\circ}$ bend. Unbent seedlings served as controls for this treatment.

The treatments were applied in all possible combinations, resulting in 18 treatment combinations in a $3 \times 3 \times 2$ factorial.

Once or twice a year the study area was mowed to control weeds and grass. Fall mowing facilitated measuring and protected against a killing wildfire.

A heavy infestation of tipmoths (Rhyacionia sp.) and spider mites (Oligonychus sp.) developed during the summer of 1960 in spite of spraying on May 23 with a mixture of DDT ( $1 \%$ solution) and Kelthane (14.8 $\mathrm{ml}$ per 3.8 liter of water $)^{1}$. Therefore, all trees under $1.5 \mathrm{~m}$ tall were sprayed at monthly intervals during March through August of 1961 through 1964 with a mixture of benzene hexachloride $(0.5 \%$ solution $)$ and Kelthane $(14.8 \mathrm{ml}$ per 3.8 liter of water). This combination of insecticide and miticide eliminated these pests as a confounding factor affecting survival and growth.

'This publication reports research involving pesticides. It does not contain recommendations for their use, nor does it imply that the uses discussed here have been registered. All uses of pesticides must be registered by appropriate State and/or Federal agencies before they can be recommended.

CAUTION: Prestidices can be injurious to humans, domestic animals, desirable plants, and fish or other wildlife - if they are not handled or applied properly. Use al pesticides selectively and carefully. Follow recommended practices for the disposal of surplus pesticides and pesticide containers.

\section{Measurements}

All trees were measured at time of treatment to establish initial tree heights at the beginning of the growing season and again in October for six growing seasons thereafter. Survival was determined from records of living trees in each five-tree transect every October. In 1960, mortality was assessed on five dates in July, August, and September to determine how soon treatments affected seedlings.

\section{Statistical Analyses}

Data on tree survival and height growth for each age-attreatment were subjected to an analysis of variance for a split-plot design of a $3 \times 3 \times 2$ factorial. Percentage of survival was analyzed after arc sine transformation of the data. Tukey's $w$ procedure at the 0.05 level was used to test differences among means when the analysis for variance indicated that significant differences were present (Steel and Torrie 1960).

\section{Results and Discussion}

\section{Survival}

Most mortality occurred shortly after treatment. In 1960, overall survival was $69 \%$. Among the seedlings that died after being treated on June 13 of that year, $50 \%$ had died by July 5, 30\% more the July 27, $12 \%$ more by August 18, 5\% more by September 12, and the final 3\% by October 17 .

Table 1 shows that few deaths occurred during the second through the sixth year. Apparently a slash pine seedling that survives an injury for a month or two can live a normal lifespan.

\section{Treated at 6 Months}

Slash pine treated 6 months after planting suffered considerable mortality (Table 1), which was partially caused by tipmoth and spider mite attacks in 1960. However, seedlings transplanted recently would be expected to be sensitive to these harsh treatments. Foliage removal and stem bending had the strongest impact, especially when applied in combination at the highest intensities (Fig. 2). Although the higher intensities of each treatment increased mortality, only the most severe treatments caused mortality to be significantly greater than the control.

Stem bending combined with foliage removal caused far greater mortality when all foliage was removed than when only half was removed. This interaction was significant only in the sixth year, but similar differences were present previously.

When treatments were applied at less than the highest intensity, survival was at levels that would result in adeTable 1. Survival $(\%)$ of slash pine over a 6-year period as affected by various intensities of foliage removal, shoot removal, and stem bending at three
plantation ages. 1

\begin{tabular}{|c|c|c|c|c|c|c|c|c|c|c|c|}
\hline \multicolumn{3}{|c|}{ Treatments $^{1}$} & \multirow{2}{*}{\multicolumn{3}{|c|}{ Treated 6 mo. after planting }} & \multirow{2}{*}{\multicolumn{3}{|c|}{ Treated $18 \mathrm{mo}$. after planting }} & \multirow{2}{*}{\multicolumn{3}{|c|}{ Treated 30 mo. after planting }} \\
\hline \multirow{2}{*}{$\begin{array}{l}\text { Foliage } \\
\text { removal } \\
(\%) \\
\end{array}$} & \multirow{2}{*}{$\begin{array}{l}\text { Shoot } \\
\text { removal } \\
(\%)\end{array}$} & \multirow{2}{*}{$\begin{array}{l}\text { Stem } \\
\text { bending } \\
(\%)\end{array}$} & & & & & & & & & \\
\hline & & & $1 \mathrm{yr}$. & $2 \mathrm{yr}$. & $6 \mathrm{yr}$. & $1 \mathrm{yr}$ & $2 \mathrm{yr}$. & $6 \mathrm{yr}$. & $1 \mathrm{yr}$. & $2 \mathrm{yr}$. & $6 \mathrm{yr}$. \\
\hline 0 & All & All & $90.4 \mathrm{a}$ & $89.6 \mathrm{a}$ & $88.5 \mathrm{a}$ & $98.1 \mathrm{ab}$ & $98.1 \mathrm{a}$ & $97.4 \mathrm{a}$ & 99.6 & 99.6 & 97.4 \\
\hline 50 & All & All & $87.0 \mathrm{a}$ & $86.3 \mathrm{a}$ & $82.2 \mathrm{a}$ & $99.3 \mathrm{a}$ & $98.9 \mathrm{a}$ & $96.3 \mathrm{a}$ & 99.6 & 99.6 & 97.4 \\
\hline 100 & All & All & $50.0 \mathrm{~b}$ & $47.8 \mathrm{~b}$ & $45.6 \mathrm{~b}$ & $89.3 b$ & $87.4 \mathrm{~b}$ & $83.7 \mathrm{~b}$ & 98.1 & 98.1 & 94.4 \\
\hline All & 0 & All & $81.5 \mathrm{a}$ & $80.7 \mathrm{a}$ & $78.5 \mathrm{a}$ & $97.4 \mathrm{a}$ & $97.4 \mathrm{a}$ & $95.6 \mathrm{a}$ & 100.0 & 100.0 & 97.4 \\
\hline All & 50 & All & $76.3 \mathrm{ab}$ & $75.2 b$ & $72.6 \mathrm{ab}$ & $97.4 \mathrm{a}$ & $96.3 \mathrm{a}$ & $93.7 \mathrm{a}$ & 98.5 & 98.5 & 95.2 \\
\hline All & 100 & All & $69.6 \mathrm{~b}$ & $67.8 \mathrm{~b}$ & $65.2 \mathrm{~b}$ & $91.9 \mathrm{~b}$ & $90.7 \mathrm{a}$ & $88.1 \mathrm{a}$ & 98.9 & 98.9 & 96.7 \\
\hline All & All & 0 & $88.4 \mathrm{a}$ & $86.9 \mathrm{a}$ & $83.7 \mathrm{a}$ & $98.0 \mathrm{a}$ & $97.8 \mathrm{a}$ & $95.8 \mathrm{a}$ & $100.0 \mathrm{a}$ & $100.0 \mathrm{a}$ & 96.5 \\
\hline All & All & 100 & $62.6 \mathrm{~b}$ & $62.2 \mathrm{~b}$ & $60.5 b$ & $93.1 \mathrm{~b}$ & $91.9 \mathrm{a}$ & $89.1 \mathrm{~b}$ & $98.3 \mathrm{~b}$ & $98.3 b$ & 96.3 \\
\hline
\end{tabular}

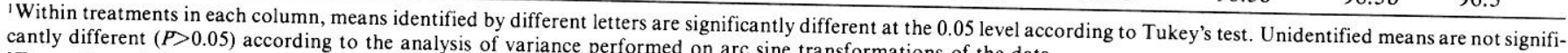
${ }^{2}$ For each survival percentage, indiate the analysis of variance performed on arc sine transformations of the data.

For survival percentage, indicated treatment was averaged across all levels of the other two treatments. 


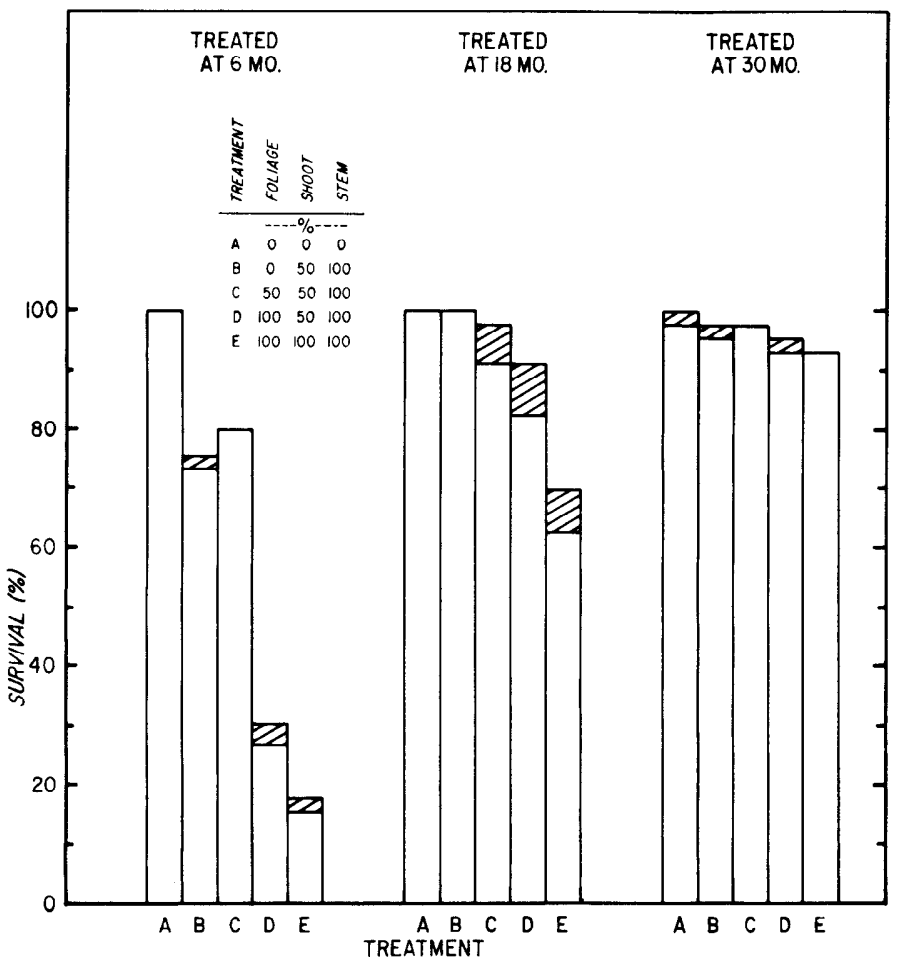

Fig. 2. Survival of slash pine treated with representative combinations of foliage removal, shoot removal, and stem bending at various intensities. Total length of bars indicates survival at 1 year; hatched portions show subsequent mortality and survival 6 years after treatment. quately stocked stands. However, the highest level of each individual treatment averaged across all levels of the other treatments always resulted in survival of less than $70 \%$ (Table 1). Combining all three treatments at the highest intensities resulted in survival of less than $18 \%$ (Fig. 2).

\section{Treated at 18 Months}

Trends in mortality of slash pine treated 18 months after planting were similar to but much less than that for seedlings treated at 6 months (Table 1). Stem bending significantly lowered survival by 5 percentage points, but foliage and shoot removal had an even greater effect. Combining all three treatments at the highest intensities resulted in firstand sixth-year survival rates of 68 and $62 \%$ (Fig. 2).

\section{Treated at 30 Months}

Almost all trees treated at 30 months after planting lived (Table 1). The only significant mortality occurred with stem bending, which killed approximately $2 \%$ of the trees.

As was the case with younger trees, combining all treatments at the highest levels caused the greatest mortality, but it was much less than in younger trees (Fig. 2). Although older slash pine apparently can live through even the severest injury, Hughes (1976) reported that South Florida slash pine (Pinus elliottii var. densa Little and Dorman) suffered considerable mortality after receiving similar injuries at this age.

\section{Heights and Growth Rates \\ Treated at 6 Months}

Seedlings treated within 6 months after planting fre-

Table 2. Annual height growth (meters) of slash pine as affected by various intensities of foliage removal, shoot removal, and stem bending applied at three plantation ages. ${ }^{1}$

\begin{tabular}{|c|c|c|c|c|c|c|c|c|c|}
\hline & Treatn & & & & & & & & \\
\hline $\begin{array}{l}\text { Foliage } \\
\text { removal }\end{array}$ & $\begin{array}{l}\text { Shoot } \\
\text { removal }\end{array}$ & $\begin{array}{l}\text { Stem } \\
\text { bending }\end{array}$ & & & & seasons & treatme & & \\
\hline & & $(\%)$ & 1 & 2 & 3 & 4 & 5 & 6 & Total \\
\hline & & & & & Treate & months & & & \\
\hline 0 & All & All & $0.15 \mathrm{a}$ & $0.30 \mathrm{a}$ & $0.52 \mathrm{a}$ & $0.67 \mathrm{a}$ & $0.91 \mathrm{a}$ & $1.01 \mathrm{a}$ & $3.45 a$ \\
\hline 50 & All & All & $0.13 \mathrm{ab}$ & $0.24 b$ & $0.49 \mathrm{a}$ & $0.64 a$ & $0.85 a$ & $1.01 \mathrm{a}$ & $3.35 \mathrm{a}$ \\
\hline 100 & All & All & $0.11 \mathrm{~b}$ & $0.15 \mathrm{c}$ & $0.37 \mathrm{~b}$ & $0.49 b$ & $0.67 b$ & $0.88 \mathrm{~b}$ & $2.65 \mathrm{~b}$ \\
\hline All & 0 & All & $0.21 \mathrm{a}$ & $0.27 \mathrm{a}$ & $0.49 \mathrm{a}$ & $0.70 \mathrm{a}$ & $0.88 \mathrm{a}$ & $1.04 \mathrm{a}$ & $3.60 \mathrm{a}$ \\
\hline All & 50 & All & $0.13 b$ & $0.24 \mathrm{a}$ & $0.43 a$ & $0.61 \mathrm{~b}$ & $0.79 a b$ & $0.94 \mathrm{ab}$ & $3.14 \mathrm{~b}$ \\
\hline All & 100 & All & $0.06 \mathrm{c}$ & $0.18 \mathrm{~b}$ & $0.43 a$ & $0.55 b$ & $0.76 \mathrm{~b}$ & $0.91 \mathrm{~b}$ & $2.90 \mathrm{~b}$ \\
\hline All & All & 0 & $0.15 a$ & $0.24 \mathrm{a}$ & 0.46 & 0.61 & 0.85 & $1.01 \mathrm{a}$ & $3.32 \mathrm{a}$ \\
\hline All & All & 100 & $0.13 a$ & $0.21 \mathrm{a}$ & 0.43 & 0.61 & 0.79 & $0.91 b$ & $3.11 \mathrm{a}$ \\
\hline & & & & & Treate & 3 months & & & \\
\hline 0 & All & All & $0.30 \mathrm{a}$ & $0.58 \mathrm{a}$ & $0.76 a$ & $0.98 \mathrm{a}$ & $1.07 \mathrm{a}$ & $1.16 \mathrm{a}$ & $4.88 \mathrm{a}$ \\
\hline 50 & All & All & $0.24 b$ & $0.52 \mathrm{~b}$ & $0.73 a$ & $0.94 a$ & $1.04 \mathrm{ab}$ & $1.13 \mathrm{ab}$ & $4.60 \mathrm{~b}$ \\
\hline 100 & All & All & $0.21 \mathrm{c}$ & $0.34 \mathrm{c}$ & $0.58 \mathrm{~b}$ & $0.82 b$ & $0.98 b$ & $1.10 \mathrm{~b}$ & $4.02 c$ \\
\hline All & 0 & All & $0.34 \mathrm{a}$ & $0.57 \mathrm{a}$ & $0.76 \mathrm{a}$ & $0.98 \mathrm{a}$ & $1.07 \mathrm{a}$ & 1.13 & $4.82 \mathrm{a}$ \\
\hline All & 50 & All & $0.27 b$ & $0.46 \mathrm{~b}$ & $0.67 \mathrm{~b}$ & $0.88 b$ & $1.04 \mathrm{ab}$ & 1.16 & $4.48 b$ \\
\hline All & 100 & All & $0.13 c$ & $0.46 \mathrm{~b}$ & $0.64 b$ & $0.85 b$ & $0.98 \mathrm{~b}$ & 1.10 & $4.21 \mathrm{c}$ \\
\hline All & All & 0 & $0.27 \mathrm{a}$ & 0.49 & 0.70 & 0.91 & $1.04 \mathrm{a}$ & $1.16 \mathrm{a}$ & $4.57 \mathrm{a}$ \\
\hline All & All & 100 & $0.24 b$ & 0.49 & 0.67 & 0.91 & $1.01 \mathrm{a}$ & $1.13 \mathrm{a}$ & $4.42 \mathrm{a}$ \\
\hline & & & & & Treate & months & & & \\
\hline 0 & All & All & $0.43 a$ & $0.67 \mathrm{a}$ & $0.91 \mathrm{a}$ & $1.04 \mathrm{ab}$ & 1.16 & $1.16 \mathrm{a}$ & $5.40 \mathrm{a}$ \\
\hline 50 & All & All & $0.37 b$ & $0.6 \mathrm{lb}$ & $0.88 \mathrm{a}$ & $1.07 \mathrm{a}$ & 1.16 & $1.13 \mathrm{ab}$ & $5.15 \mathrm{a}$ \\
\hline 100 & All & All & $0.30 \mathrm{c}$ & $0.40 \mathrm{c}$ & $0.73 \mathrm{~b}$ & $0.94 b$ & 1.10 & $1.07 \mathrm{~b}$ & $4.51 \mathrm{~b}$ \\
\hline All & 0 & All & $0.49 a$ & $0.58 \mathrm{a}$ & 0.88 & $1.04 \mathrm{a}$ & 1.16 & 1.13 & $5.24 \mathrm{a}$ \\
\hline All & 50 & All & $0.43 a$ & $0.52 \mathrm{~b}$ & 0.82 & $0.98 \mathrm{a}$ & 1.13 & 1.13 & $5.00 \mathrm{ab}$ \\
\hline All & 100 & All & $0.18 b$ & $0.58 \mathrm{a}$ & 0.82 & $1.04 \mathrm{a}$ & 1.13 & 1.10 & $4.79 \mathrm{~b}$ \\
\hline All & All & 0 & 0.37 & 0.55 & 0.85 & 1.01 & 1.13 & 1.13 & 5.03 \\
\hline All & All & 100 & 0.37 & 0.55 & 0.85 & 1.01 & 1.13 & 1.10 & 5.00 \\
\hline
\end{tabular}

I Within treatment groups in each column, means identified by different letters are significantly different at the 0.05 level according to Tukey's test. Unidentified means are not statistically different $(P>0.05)$ according to the analysis of variance.

${ }^{2}$ For each growth mean, indicated treatment was averaged across all levels of the other two treatments. 


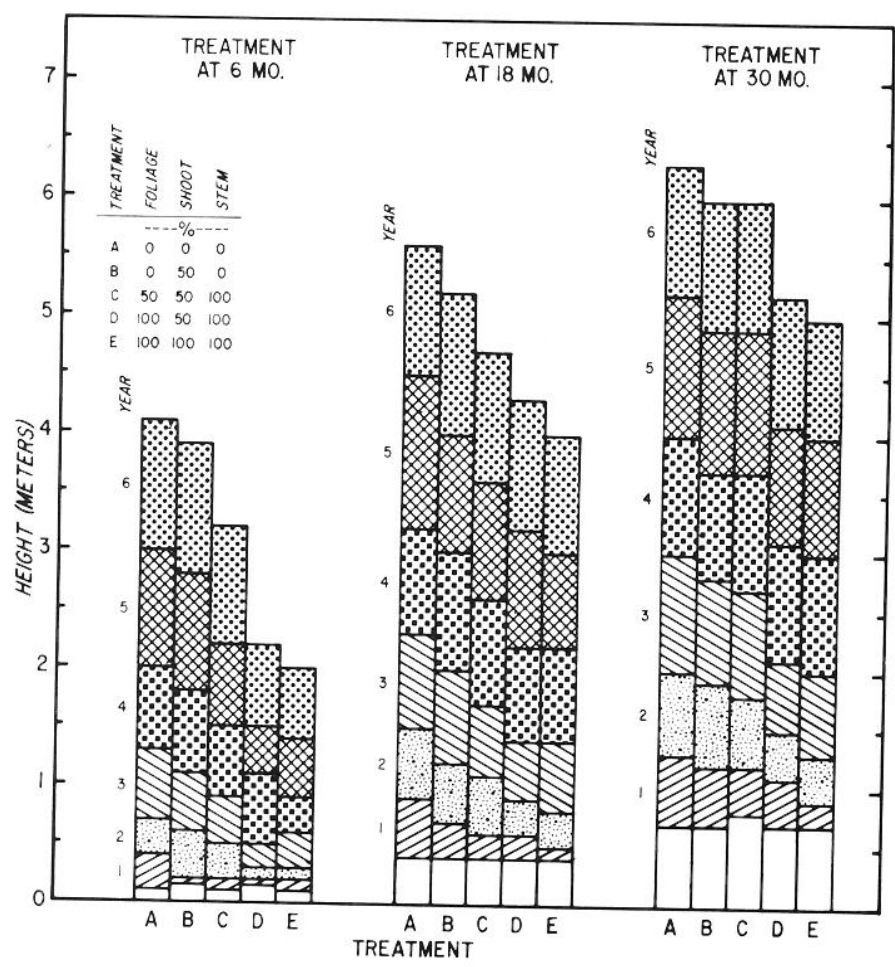

Fig. 3. Initial height at time of treatment (bottom segment of bars), final heights, and annual growth for 6 years after various combinations of foliage removal, shoot removal, and stem bending of slash pine treated at 3 ages after planting. Detailed tables are available from the author.

quently exhibited reduced height growth throughout the study (Table 2). During the first year, shoot removal caused the greatest reduction because the first flush of growth had been removed with the terminal bud. Thereafter, needle removal caused the greatest reduction in height growth, especially when combined with either shoot removal or stem bending (Fig. 3). Only defoliation at the highest intensity significantly affected height growth after the first 2 years. Any early losses in height persisted throughout the study. After 6 years, trees that had received the most severe treatments in combination were only half as tall as the untreated controls.

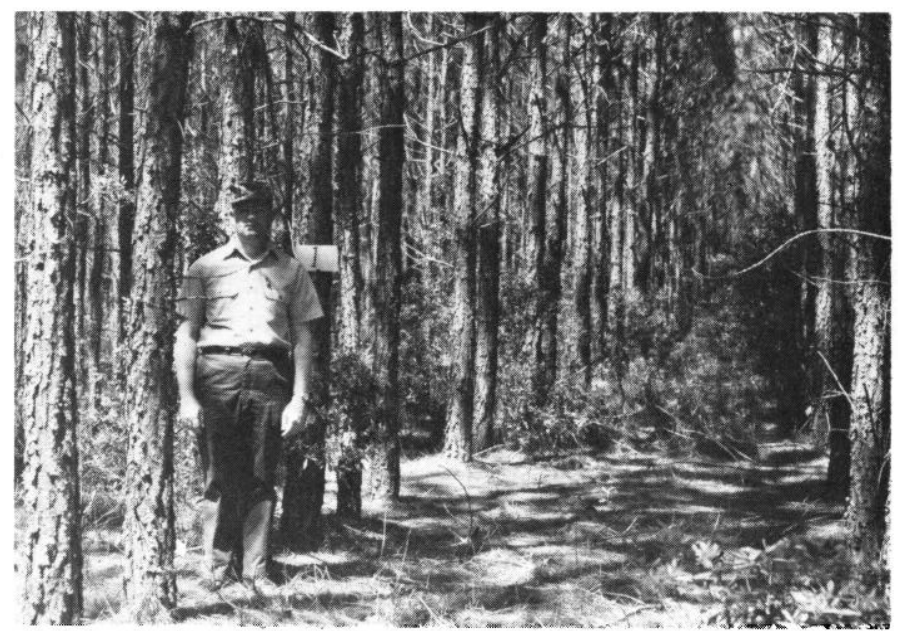

Fig. 4. Slash pine seedlings planted and treated in 1960 exhibit good growth and form. The two trees in front of the technician were subjected to $50 \%$ foliage removal, 100\% shoot removal, and stem bending; the six trees behind him were untreated.
Significant interaction between foliage and shoot removal during the first growing season indicated that combining either degree of shoot removal with complete foliage removal had a much greater impact on height growth than did combinations involving a lesser degree of defoliation. The most persistent interaction occurred from combining foliage removal with stem bending; combining the highest levels of each treatment produced a stronger response than did combinations involving lower levels. Overall, the young seedlings withstood considerable injury before any real damage occurred (Fig. 4).

\section{Treated at 18 Months}

Treatments applied 18 months after outplanting significantly reduced annual height growth (Table 2). Shoot removal had the greatest impact during the first growing season; thereafter, foliage removal had the greatest impact.

Growth loss from removing $50 \%$ of the shoots was small, despite removal of $0.2 \mathrm{~m}$ of the initial growth during the year of treatment. Removing $100 \%$ of the shoots resulted in growth loss of only $0.6 \mathrm{~m}$ after 6 years.

Complete foliage removal from seedlings at 18 months after planting reduced tree heights about $0.9 \mathrm{~m}$ after six growing seasons, while $50 \%$ foliage removal reduced heights by less than $0.3 \mathrm{~m}$. The major impact from removing $100 \%$ of the foliage disappeared after the fourth year.

Stem bending at 18 months after planting had little effect on heights or height growth. Although statistically significant during the first year, the differences were never more than $0.03 \mathrm{~m}$ in any year and only reduced heights by $0.2 \mathrm{~m}$ in 6 years.

Combining treatments placed considerable stress on the trees, but only the severest levels or combinations drastically reduced height growth (Fig. 3). Combining all treatments at the highest level reduced heights by just over $1.5 \mathrm{~m}$ in 6 years, with an observable decrease in tree diameter. However, this combination had little effect on tree form. Some trees that received the most severe combination of treatments made excellent recovery, although most were stunted. Regardless of treatment, nearly normal growth rates were usually attained after the third growing season.

\section{Treated at 30 Months}

Reductions in height growth were less when treatments were applied 30 months after planting than when they were applied to younger seedlings (Table 2). Shoot removal at 30 months had the greatest impact during the year of treatment, while foliage removal was more important in remaining years. Stem bending did not affect growth.

Total defoliation reduced growth somewhat throughout the study, but removal of half the needle length reduced growth for only 2 years. After 6 years, maximum growth losses from defoliation were slightly less than $0.9 \mathrm{~m}$.

Combining all treatments at the highest intensities caused the greatest loss in tree growth during the first year (Fig. 5) and some loss during the second year. Removal of all shoots with any level of foliage removal was especially detrimental during the first year but not during the second year (Fig. 3). After 3 years, growth rate returned to normal, regardless of the treatment. Six years after treatment, untreated trees were almost $6.4 \mathrm{~m}$ tall, whereas treated trees were as much as $1.2 \mathrm{~m}$ shorter.

\section{Year of Planting}

The years of planting and of applying treatments in this 


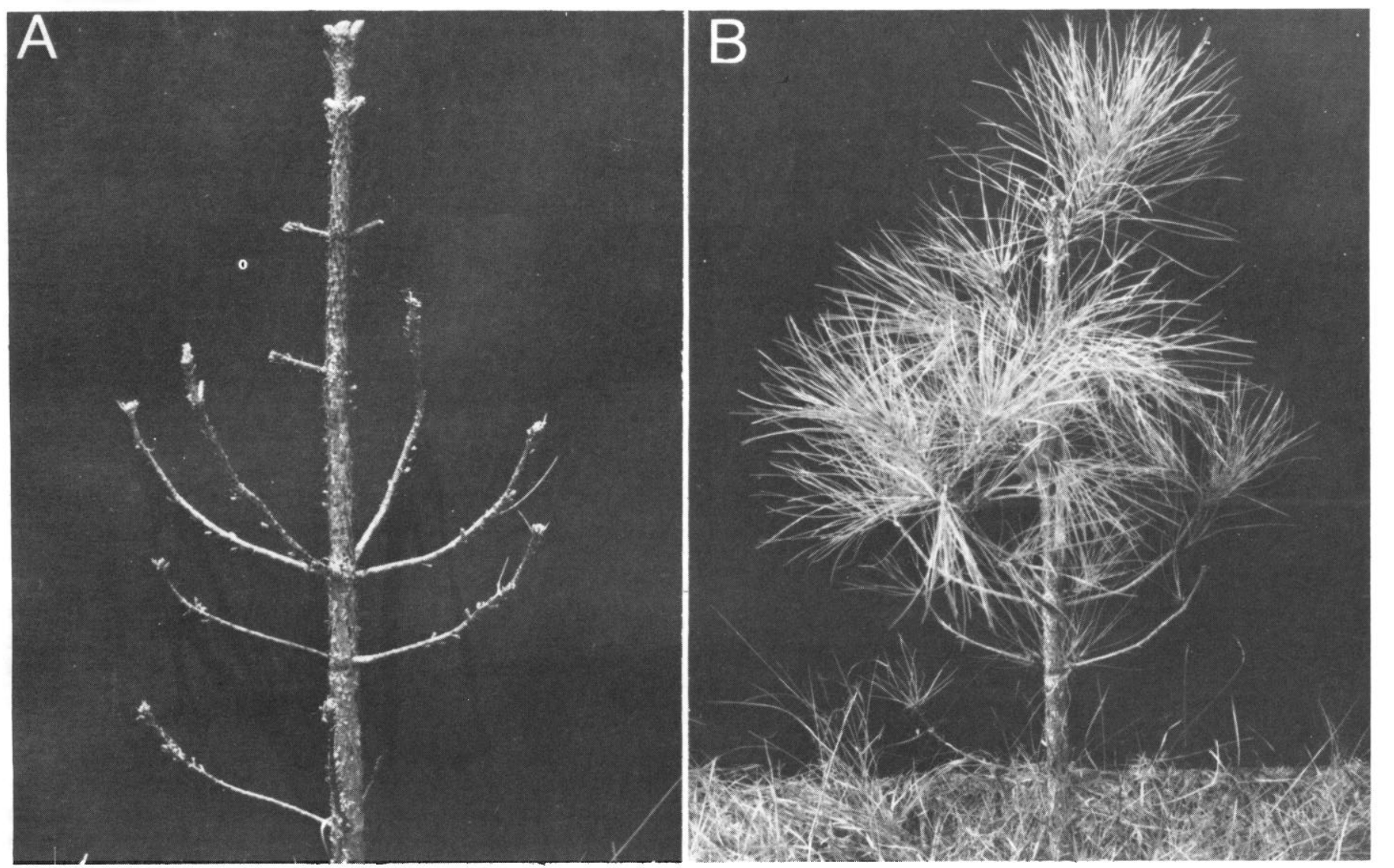

Fig. 5. Removing all foliage and shoots, then bending the stem, proved the most severe and detrimental treatment when applied at 30 months after planting (A); yet, recovery within 5 months was good (B).

study encompassed the wettest and driest years during the 10 -year period. In 1962, rainfall during the growing season was $25.4 \mathrm{~cm}$ below the long-term average. In 1964, heavy rainfall kept the soil saturated throughout the growing season. No temperature extremes occurred in any year.

There was some significant variation in height growth and survival among seedlings planted and treated on the various dates, even though the seedlings had been graded prior to planting in order to provide uniform stands. Yearly differences in weather undoubtedly accounted for some of this variation. For example, among seedlings treated at 30 months, those planted in 1962 were significantly shorter at the end of the sixth growing season than those planted in 1960 and 1961. Presumably, the former were stunted by the reduced rainfall during their initial growing season and by the heavy rainfall during the first growing season after treatment. However, weather did not explain other differences in growth and survival. Some of these may have resulted from differences in seedlots. Thus, differences in weather during the years of planting were apparently not of paramount importance in determining seedling response.

\section{Summary and Conclusions}

Seedling mortality after injury occurred almost immediately. Of the first-year deaths recorded on seedlings treated 6 months after planting, $50 \%$ died in less than a month, and 92\% died within 2 months. Little mortality occurred in following years. In grazing trials, Pearson et al. (1971) found that $80 \%$ of tree mortality occurred in the months imme- diately after planting; suggested withholding heavy grazing until about June 1 of the first year. If grazing can be withheld during the first year after planting, almost no mortality will occur. In later years, the primary injury comes from cattle rubbing the lower branches or riding down saplings to rub insects off themselves (Wakeley 1954).

Survival was excellent when treatments were applied at 30 months after planting and was only slightly poorer at 18 months. Greatest mortality occurred at 6 months after planting when the highest intensities of each type of injury were applied, especially when they were combined. Slash pine seedlings apparently can take a tremendous amount of injury before they are killed. Pearson (1931) reached similar conclusions for ponderosa pine (Pinus ponderosa Laws.) after a 14-year study in northern Arizona. Cassady et al. (1955) reported that only $2 \%$ of southern pine seedlings died in a broad survey of cattle damage in Louisiana. Pearson et al. (1971) reported 4 to $5 \%$ mortality to both planted and seeded slash pine on rangeland being grazed continuously.

Injuries to seedlings had a greater impact on heights and growth rates when inflicted within 6 months after planting then when inflicted on older seedlings. Shoot removal had the greatest effect on height growth during the first year, but foliage removal had the greatest effect overall.

Growth rates were not greatly affected unless combinations of injuries at the higher intensities were applied. Removing all foliage and all shoots and then bending the stem parallel to groundline reduced the growth of 6-monthold seedlings by one-half, but lower levels of injury were 
much less damaging. Similar trends occurred when treatments were applied to older trees, however, the losses in height were less. Thus, it is not surprising that grazing has been reported to have no detectable effect on slash and longleaf pine except under conditions of heavy stocking or concentration of animals (Wahlenberg et al. 1939; Halls et al. 1952; Pearson et al. 1971). Currie et al. (1978) reported similar responses by ponderosa pine in Colorado. However, since rates of cattle stocking are not always controlled, world-wide examples of extreme damage are common (Adams 1975).

Yearly replication of all plantings and treatments proved advantageous in this study. Although trends in response to treatment were similar each year, the magnitude of the responses sometimes differed. Growth rates exhibited variations associated with year of planting, but usually these were small. Some differences, however, equalled those measured in response to treatments.

Slash pine demonstrates a tremendous ability to survive extreme forms and intensities of injury. It also exhibits strong resiliency to injury and rapid recovery of growth. These characteristics have contributed to the compatibility between livestock, deer, and pines in the southern forests. Other southern pines, indeed most pines, probably possess these characteristics to a similar degree. If cattle stocking is kept in balance with available forage, little damage to pines will occur. When injuries do occur, this study provides data for determining what type of injury is truly damaging and the growth loss that can be expected.

\section{Literature Cited}

Adams, S.N. 1975. Sheep and cattle grazing in forests: a review. J. Appl. Ecol. 12: 143-152.

Cassady, J.T., W. Hopkins, and L.B. Whitaker. 1955. Cattle damage to pine seedlings. U.S. Dep. Agr. Forest Serv., South. Forest Exp. Sta. Occas. Pap. 141,14 p.

Currie, P.O., C.B. Edminster, and F.W. Knott. 1978. Effects of cattle grazing on ponderosa pine regeneration in central Colorado. U.S. Dep. Agr. Forest Serv., Rocky Mt. Forest and Range Exp. Sta. Res. Pap. RM-201, 7 p.

Halls, L.K., B.L. Southwell, and F.E. Knox. 1952. Burning and grazing in Coastal Plain forests. Ga. Agr. Exp. Sta., Ga. Coastal Plain Exp. Sta. Bull. $51,33 \mathrm{p}$.

Hilmon, J.B., C.E. Lewis, and J.E. Bethune. 1963. Highlights of recent results of range research in southern Florida. In: Soc. $\Lambda$ mer. Forest. Proc. 1962: 73-76.

Hughes, R.H. 1976. Response of planted South Florida slash pine to simulated cattle damage. J. Range Manage. 29: 198-201.

Pearson, G.A. 1931. Recovery of western yellow pine seedlings from injury by grazing animals. J. Forest. 29: 876-894.

Pearson, H.A. 1976. Botanical composition of cattle diets on a southern pine-bluestem range. U.S. Dep. Agr. Forest Serv., South. Forest Exp. Sta. Res. Note SO-216, 3 p.

Pearson, H.A., L.B. Whitaker, and V.L. Duvall. 1971. Slash pine regeneration under regulated grazing. J. Forest. 69: 744-746.

Steel, R.G.D., and J.H. Torrie. 1960. Principles and Procedures of Statistics. McGraw-Hill Book Co., Inc., New York. 481 p.

Smith, L.F., R.S. Campbell, and C.L. Blount. 1958. Cattle grazing in longleaf pine forests of south Mississippi. U.S. Dep. Agr. Forest Serv., South. Forest Exp. Sta. Occas. Pap. 162, 25 p.

Wahlenberg, W.G., S.W. Greene, and H.R. Reed. 1939. Effects of fire and cattle grazing on longleaf pine lands as studied at McNeill, Mississippi. U.S. Dep. Agr. Tech. Bull. 683, 52 p.

Wakeley, P.C. 1954. Planting the southern pines. U.S. Dep. Agr. Agr. Monogr. 18, $233 \mathrm{p}$.

Williston, H.L. 1974. Control of animal damage to young plantations in the South. J. Forest. 72: 78-81. 